\title{
Implementasi Pembelajaran Perkembangan Mental Anak Berkebutuhan Khusus (ABK) di Sekolah Alam Mi Bilingual Al-Ikhlas Kepanjen Malang
}

\author{
Muhammad Husni \\ Dosen IAI Al-Qolam Gondanglegi Malang \\ E-mail: husninanang73@gmail.com
}

\begin{abstract}
The Implementation of the learning is the process of implementing learning in implementing a structured plan or program in carrying out the learning process. For the application of learning, there are there companion teachers who handle children of heaven experts. When students are about to the start learning, they are always given finger test therapy, so that the companion teacher can find out which part of the brain is more active. The learning approach uses an individual approach and uses an individual curriculum combined with the 2013 curriculum. This study used a qualitative approach with qualitative descriptive research. The proof obtained were written proof in accordance with the interview guidelines. The use of documentation Proof a collection techniques includes: principal proof, educator proof, student proof, learning programs for children with special needs

The application of learning to the power development of children with special needs $(A B K)$ is to use an individual curriculum combined with the 2013 curriculum and the learning uses an individual approach. Before learning begins, the companion teacher always provides finger test therapy for children before starting learning. The teacher's effort in improving children's the power development is to provide opportunities to answer questions / work on questions given by the teacher and give Stars / Rewards.
\end{abstract}

Keywords: the Learning Implementation, the power of the Development

\section{Pendahuluan}

Pendidikan merupakan proses seseorang menjadi dirinya sendiri yang tumbuh dan berjalan seiring dengan bakat, dan kemampuannya. Pendidikan berlangsung seumur hidup dan dilaksanakan di dalam lingkungan keluarga, sekolah, teman, sahabat, dan masyarakat. Di desa Sengguruh Kecamatan kepanjen tepatnya, telah berdiri sebuah Madrasah, yang bernama "Madrasah Ibtidaiyah Bilingual Al-Ikhlas". Konsep sekolah Madrasah Ibtidaiyah ini cukup unik, meski sekolah formal tapi dikemas layaknya sekolah yang akrab dengan keindahan alam karna sekolah ini berada di pinggir sawah. Di sebelah utara dan selatan ada banyak pohon tebu, sedangkan di bagian barat dan timur terdapat hamparan padi yang sangat luas. Sekolah ini didirikan oleh Prof. Dr. Wahyudi Siswanto, M.Pd guru besar Sastra Indonesia UM. 
Bangunan sekolah alam ini sangatlah berbeda dengan bangunan sekolah pada umumnya yang biasanya bangunannya berbatas dengan tembok, sedangkan bangunan sekolah alam ini tempat kelasnya menyerupai gazebo yang besarnya sekitar $5 \times 6 / \mathrm{m}^{2}$. Yang membuat suasana kelas semakin nyaman, dinding kelasnya bukanlah dari tembok tetapi dari anyaman bambu yang dipadukan dengan pohon kelapa (glugu). Meskipun berada diruang kelas, semilir angin masuk dari celah anyaman bambu yang membuat mereka semakin nyaman dan lupa kalau mereka sedang berada di dalam ruangan sekolah formal.

Di sekolah alam MI Bilingual Al-Ikhlas Desa Sengguruh ini memiliki program khusus yaitu program pendidikan inklusif. Dengan adanya pendidikan inklusif ini agar dapat menghargai keberagaman ataupun perbedaan, dan yakin bahwa setiap individu dapat berkembang sesuai dengan kemampuan yang dimilikinya. Melalui pendidikan inklusif, anak berkebutuhan khusus dididik bersama dengan anak normal lainnya pada tempat yang sama dengan layanan yang berbeda. Anak berkebutuhan khusus perlu diberikan kesempatan dan peluang yang sama seperti anak normal umumnya dan mendapatkan layanan pendidikan yang sama.

Sekolah Alam MI Bilingual Al-Ikhlas desa sengguruh Kepanjen sebagai penyelenggara pendidikan inklusif menerima anak berkebutuhan khusus. Pada tahun ajaran 2018/2019 memiliki peserta didik berkebutuhan khusus sebanyak 8 anak yang terdiri dari kelas I = 3 anak, kelas II = 2 anak, kelas III = 2 anak, kelas IV = 1 anak. Pembelajarannya di bagi menjadi 2 : (1) Bimbingan Kelas / Klasikal, (2) Bimbingan Individual / Spesial. Untuk bimbingan kelas / klasikal ada 4 anak yang sudah mengikuti pembelajaran di kelas bersama dengan anak normal lainnya dan pembelajarannya sudah mengikuti Kurikulum 2013 dan kadang-kadang masih dipantau dalam setiap pembelajarannya dan juga masih dilakukan terapi. Dan 4 anak lainnya masih berada di kelas bimbingan individual / spesialis yang pembelajarannya masih menggunakan kurikulum individual yang dikombinasikan dengan Kurikulum 2013. Kurikulum individual / spesialis ini di padukan dengan kemampuan masing-masing anak dan diberikan terapi dalam setiap minngunya.

Implementasi pembelajaran di Sekolah Alam MI Bilingual Al-Ikhlas di Desa Sengguruh Kepanjen memiliki Guru Pendamping (GP) khusus untuk Anak Berkebutuhan Khusus (ABK) dalam proses pembelajarannya. Menurut guru pendamping, siswa tersebut diberikan bimbingan khusus dalam setiap pembelajaran seperti sebelum mulai pembelajaran selalu diberikan terapi tes jari agar guru pendamping mengetahui bagian otak mana yang lebih aktif. Selain itu, siswa tersebut memiliki respon yang baik ketika apa yang telah diketahuinya dalam proses pembelajaran tersebut, 
dia mampu memberikan beberapa respon atau pertanyaan. Sampai pola makannya benar-benar diperhatikan, karena usus mereka adalah otak kedua bagi mereka. Tantangan paling utama bagi mereka adalah permen dan semua jenis tepung, jika mereka salah makan sangat berpengaruh terhadap sikap dan tingkah lakunya.

\section{Kajian Literatur}

Secara sederhana implementasi pembelajaran yaitu pelaksanaan atau penerapan dalam pembelajaran. Secara garis besar implementasi pembelajaran adalah suatu tindakan atau pelaksanaan dari sebuah perencanaan yang tersusun dalam melakukan proses pembelajaran. ${ }^{1}$ Implementasi pembelajaran merupakan suatu proses peletakan ke dalam praktik tentang ide suatu program aktivitas baru bagi seseorang dalam mencapai perubahan dalam diri orang yang diajarkan. ${ }^{2}$ Sedangkan di sisi lain berpendapat bahwa, implementasi pembelajaran merupakan suatu penerapan proses interaksi peserta didik dengan seorang guru dan sumber belajar pada suatu lingkungan belajar yang meliputi guru dan siswa saling memberikan informasi pengetahuan. ${ }^{3}$ Dari beberapa pengertian di atas dapat disimpulkan bahwa implementasi pembelajaran adalah proses penerapan dalam pembelajaran dalam melaksanakan perencanaan atau program yang tersusun dalam melaksanakan proses pembelajaran.

a. Konsep dan perkembangan pendekatan pembelajaran

Pendekatan adalah cara umum dalam memandang suatu permasalahan, dalam hal ini adalah pendekatan pembelajaran. Dalam pembelajaran sendiri mengenal pendekatan pembelajaran dalam dua jenis yaitu pendekatan yang berpusat pada siswa dan pendekatan yang berpusat pada pengajar / guru. Dari dua pendekatan ini tentunya sama-sama memiliki keunggulan dan kelemahan masing-masing. Yang perlu dilihat adalah seberapa cocok pendekatan yang diterapkan pada proses pembelajaran.

b. Jenis-jenis pendekatan pembelajaran dalam proses belajar mengajar

Proses interaksi pembelajaran yang mampu meningkatkan hasil belajar pada siswa adalah bagaimana cara guru melakukan pendekatan yang sesuai dengan karakter siswa, kurikulum dan materi pembelajaran. Sehingga seorang pendidik harus tahu jenis-jenis

\footnotetext{
${ }^{1}$ Nurdin dan Usman, Implementasi Pembelajaran, (Yokyakarta: Rajawali Pers, 2011), hlm. 34

${ }^{2}$ Asep Jihad Dan Abdul Haris, Op. Cit, hlm. 26

${ }^{3}$ Hamzah B. Uno, Perencanaan Pembelajaran, (Jakarta: Bumi Aksara, 2012), hlm. 02
} 
pendekatan pembelajaran. ${ }^{4}$ Adapun jenis-jenis pendekatan pembelajaran antara lain : 1 . Pendekatan Individual, 2. Pendekatan Kelompok, 3. Pendekatan Bervariasi, 4. Pendekatan edukatif, 5. Pendekatan keagamaan, 6. Pendekatan kebermaknaan, 7. Pendekatan deduktif, 8. Pendekatan induktif, 9. (Student-Centred Learning), 10. Pembelajaran aktif (Aktive Learning), 11. Pendekatan konstruktivisme, 12. Contextual Teaching and Learning, 13. Cooperative learning, 14. Creative learning, 15. Inquiri dan discovery, 16. Problem solving, 17. Problem based learning.

c. Rancangan implementasi pendekatan pembelajaran dalam proses belajar mengajar

Dalam merancang implementasi pendekatan pelajaran, harus disesuaikan dengan perubahan kurikulum yang sudah berlangsung. Salah satu kurikulum yang sedang diterapkan pada masa sekarang adalah kurikulikm tahun 2013 (K13). Untuk menentukan pendekatan pembelajaran yang cocok dalam kurikulum 2013 dapat mempertimbangkan hal-hal sebagai berikut ${ }^{5}$

1. Kesesuaian model pembelajaran dengan kompetensi sikap pada KI-1 dan KI-2 serta kompetensi pengetahuan dan keterampilan sesuai dengan KD-3 atau KD-4

2. Kesesuaian model pembelajaran dengan karakteristik KD-1 (jika ada) dan KD-2 yang dapat mengembangkan kompetensi sikap, dan kesesuaian materi pembelajaran dengan tuntutan KD-3 dan KD-4 untuk mengembangkan kompetensi pengetahuan dan keterampilannya.

3. Penggunaan pendekatan saintifik yang mengembangkan pengalaman belajar peserta didik melalui kegiatan mengamati (observing), menaya (questioning), mencoba / mengumpulkan informasi (experimenting / collecting information), mengasosiasi / menalar (assosiating), dan mengomunikasikan (communicating).

\section{Perkembangan mental}

Perkembangan mental yaitu suatu perkembangan yang terdapat pada diri seseorang baik sikap dan sifat, ataupun rasa percaya diri yang ada pada dirinya. ${ }^{6}$ Pada dasarnya pengetahuan tumbuh dan berkembang melalui pengalaman yang diperolehnya. Perkembangan mental

\footnotetext{
${ }^{4}$ Yuda Asmara, Pendekatan Pembelajaran dan Implementasi Dalam Proses Belajar Mengajar, (Jakarta:

Rineka Cipta), hlm.06

${ }^{5}$ Ibid., hlm. 13

${ }^{6}$ Https://Brainly.Co.Id/Tugas/6154982 Diakses Pada Tanggal 16 Februari 2019
} 
semakin dalam dan semakin kuat apabila selalu diuji dengan pengalam baru dan lebih menantang. Perkembangan kognitif manusia yang merupakan proses psikologi di dalamnya melibatkan proses-proses memperoleh, menyusun dan menggunakan pengetahuan, serta kegiatan-kegiatan mental, seperti : mengingat, berfikir, menimbang, mengamati, menganalisis, mengevaluasi dan memecahkan persoalan yang berlangsung melalui interaksi dengan lingkungan.

Jean Piaget tidak sependapat dengan pandangan yang mengatakan bahwa kecerdasan adalah merupakan faktor bawaan, yang berarti manusia tinggal menerima perbedaan yang ada, karena pandangan yang seperti ini akan membawa pengaruh kurang positif atau bahkan negatif terhadap proses pendidikan dan upaya pengembangan kemampuan berfikir anak. Menurut teori perkembangan kognitif Jean Piaget, ada $4 \operatorname{tahapan}^{7}$, yaitu : 1. Tahap Sensori-Motoris (usia 0-2 tahun), 2. Tahap Praoperasional (usia 2-7 tahun), 3. Tahap Operasional Konkrit (usia 7-11 tahun), 4. Tahap Operasional Formal (11 tahun ke atas).

\section{Anak Berkebutuhan Khusus (ABK)}

Anak Berkebutuhan Khusus (ABK) adalah anak yang mempunyai karakteristik khusus terkait dengan kondisi psikis dan fisiknya, sehingga ia membutuhkan seseorang dalam setiap pertumbuhan dan perkembangannya dan terutama dalam pendidikannya membutuhkan pendamping agar dapat mengoptimalkan potensi yang dimilikinya. ${ }^{8}$ Anak berkebutuhan khusus (special needs cildren) dapat diartikan sebagai anak yang terlambat (slow) atau mengalami gangguan (retarted), yang tidak bisa berhasil di sekolah seperti anak pada umumnya. Ana berkebutuhan khusus juga dapat diartikan sebagai anak yang mengalami gangguan fisik, mental, intelegensi, dan emosi sehingga butuh pembelajaran secar khusus. Banyak istilah yang dipergunakan sebagai variasi dari anak berkebutuhan khusus, seperti disability, impairment, dan handicap. Menurut World Health Organization (WHO), definisi dari masing-masing istilah itu adalah sebagai berikut ${ }^{9}$ : Disability, Impairment, Handicap.

\section{a. Etiologi Anak Berkebutuhan Khusus}

${ }^{7}$ Mohammad Asrori, Psikologi Pembelajaran, Cetakan Pertama (Bandung: CV Wacana Prima, Januari 2007), hlm. 49-51

${ }^{8}$ Nur Eva, Psikologi Anak Berkebutuhan Khusus, Cetakan Pertama (Malang: Fakultas Pendidikan Psikologi, 2015), hlm. 02

${ }^{9}$ Jati Rinakri Atmaja, Pendidikan Dan Bimbingan Anak Berkebutuhan Khusus, Cetakan Pertama (Bandung: PT Remaja Rosdakarya, 2018), hlm. 06 
Menurut Irwanto, Kasim dan Rahmi (2010), secara garis besar faktor penyebab Anak Berkebutuhan Khusus (ABK) jika dilihat dari masa terjadinya dapat dikelompokkan dalam 3 macam, yaitu ${ }^{10}: 1$. Faktor penyebab anak berkebutuhan khusus yang terjadi pra kelahiran / sebelum lahir, yaitu masa anak masih berada di dalam kandungan telah diketahui mengalami kelainan. Antara lain : gangguan genetika (kelainan kromosom / transformasi), infeksi kehamilan, usia inu hamil, keracunan saat hamil, digugurkan, dan lahir prematur. 2. Faktor penyebab anak berkebutuhan khusus yang terjadi selama proses kelahiran, ada beberapa sebab kelainan saat anak dilahirkan, antara lain : anak lahir seelum waktunya (prematur), lahir dengan alat bantu, posisi bayi tidak normal, analgesik (penghilang nyeri) dan anesthesia (keadaan narkosis), kelainan ganda atau karena kesehatan bayi kurang baik, proses kelahiran lama (anoxia), kekurangan oksigen, kehamilan terlalu lama. 3. Faktor penyebab anak berkebutuhan khusus yang terjadi setelah proses kelahiran, yaitu masa dimana kelainan itu terjadi setelah bayi dilahirkan, atau disaat anak dalam masa pertumbuhan dan berkembangan. Ada beberapa sebab kelainan anak dilahirkan anatara lain : infeksi bakteri / virus, kekurangan gizi, keracunan, dan kecelakaan.

Berdasarkan faktor tersebut, sebagian besar (70,21\%) anak berkebutuhan khusus disebabkan oleh bawaan dari lahir, kemudian karena penyakit $(15,70 \%)$ dan kecelakaan / bencana alam sebesar (10,88\%).

b. Klasifikasi Anak Berkebutuhan Khusus

1. Kelainan fisik, merupakan kelainan yang terjadi pada satu atau lebih dari organ tubuh, akibatnya timbul suatu keadaan pada fugsi fisik dan tubuhnya tidak dapat berfungsi secara normal. Tidak berfungsinya anggota tubuh terjadi $\operatorname{pada}^{11}$ : a) Alat indra fisik, misalnya kelainan pada alat indra pendengaran (tunarungu), indra penglihatan (tunanetra), dan kelainan pada fungsi bicara (tunawicara), b) Alat motorik, , misalnya kelainan otot dan tulang (poliomyelitis), kelainan pada sistem saraf otak yang berakibat gangguan pada fungsi motorik (cerebral palsy), kelainan anggota badan akibat pertumbuhan yang yang tidak sempurna, misalnya lahir dengan keadaan jari

${ }^{10}$ Nur Eva, Psikologi Anak Berkebutuhan Khusus, Cetakan Pertama (Malang: Fakultas Pendidikan Psikologi, 2015), hlm. 09

${ }^{11}$ Dinie Ratri Desiningrum, Pikologi Anak Berkebutuhan Khusus, cetakan pertama (Yogyakarta: Ruko Jambusari), hlm. 07 
tangan/kaki kurang, amputasi, dan lain-lain. Untuk kelainan pada alat motorik tubuh ini biasanya disebut cacat (tunadaksa).

2. Kelainan mental adalah anak yang memiliki penyimpangan kemampuan berfikir secara kritis, logis dalam menanggapi keadaan disekitar. Kelainan pada mental ini dapat menyebar ke dua arah, yaitu kelainan dalam arti lebih (supernormal) dan kealianan mental dalam arti kurang (subnormal). Kelainan dalam arti lebih , menurut tingkatannya dikelompokkan menjadi : a) anak mampu belajar dengan cepat (rapid learner), b) anak berbakat (gifted), c) anak genius (extremelly gifted). Karakteristik anak yang termasuk dalam kategori mampu belajar dengan cepat hasil kecerdasannya menunjukkan bahwa indeks kecerdasan berada pada rentang 110-120, kategori anak berbakat indeks kecerdasannya berada pada rentang 120-140, dan kategori anak sangat berbakat atau jenius indeks kecerdasannya berada pada rentang di atas $140 .^{12}$

3. Kelainan prilaku sosial, adalah mereka yang mengalami kesulitan untuk menyesuaikan diri / bersosialisasi terhadap lingkungan. Anak yang termasuk dalam kategori kelainan prilaku sosial adalah anak yang mempunyai tingkah laku yang tidak sesuai dengan kebiasaan yang biasanya dilakukan anak pada umumnya. ${ }^{13}$

\section{Pendidikan inklusif}

Pendidikan inklusif adalah pendidikan yang didasari semangat terbuka untuk merangkul semua orang / kalangan dalam pendidikan. Pendidikan inklusif merupakan implementasi pendidikan yang berwawasan multikural yang dapat membantu peserta didik mengerti, menerima, serta menghargai orang lain yang berbeda suku, budaya, nilai, kepribadian dan keberfungsian fisik maupun psikologisnya. Pendidikan haruslah sadar bahwa, setiap anak adalah unik dan memiliki karakteristik yang berbeda-beda dengan anak yang lainnya. Pendidikan seharusnya bisa mengakomodadi dari semua perbedaan, terbuka untuk semua dan memberikan kebutuhan yang dibutuhkan oleh setiap individu. ${ }^{14}$

\footnotetext{
${ }^{12}$ Ibid., hlm. 08

${ }^{13}$ Ibid., hlm. 09

${ }^{14}$ Muhammad Husni-IAI Al-Qolam, Diferensiasi Peserta Didik Dalam Kebersamaan Di Kelas Inklusi Sekolah Garasi Turen Malang, (Surabaya: UIN Sunan Ampel, 2018), hlm. 479
} 


\section{Sekolah alam}

Sekolah alam adalah sebuah konsep pendidikan yang digagas berdasarkan keprihatiannya akan biaya pendidikan yang semakin tidak terjangkau oleh masyarakat dan menjadikan siswa lebih dekat dengan alam saat proses pembelajaran. ${ }^{15}$ Pada dunia pendidikan konsep sekolah merupakan salah satu unsur yang paling penting untuk belangsungnya sistem pendidikan. Salah satu bentuk sintem pendidikan yang digagas untuk merubah keadaan dunia pendidikan saat ini, dan mulai dikembangkan dunia pendidikan yang melekat dengan alam yang menjadikan siswa lebih rileks meskipun berada di ruang kelas adalah pendidikan sekolah alam. ${ }^{16}$ Alam adalah sumber pengetahuan yang sangat luas, yang akan akan keindahannya.

Sekolah alam merupakan sekolah yang berbasiskan alam serta memanfaatkan alam sebagai media / penerapan pembelajaran. Sekolah alam bukan hanya mengajak siswa lebih dekat dengan alam, tetapi sekolah alam ini berusaha memanfaatkan alam sebagai media untuk pembelajaran secara optimal. Siswa diberikan kebebasan dalam menuangkan kreatifitas yang sesuai dengan bakat dan kemampuan mereka. Itulah mengapa sebagian besar aktivitas pembelajaran dilakukan di ruang alam bebas. Siswa diajak langsung berinteraksi dengan alam disekitar lokasi sekolah. alam memberikan banyak inspirasi dan mengajak siswa belajar lebih kreatif. ${ }^{17}$ Sistem sekolah alam ini sangat berbeda dengan sekolah formal pada umumnya. Sekolah alam hadir dengan konsep pendidikan yang berbeda. Sekolah bukan lagi menjadi beban dengan biaya yang semakin mahal, tetapi sekolah alam adalah realitas kehidupan yang mereka jalani sehari-hari. Sekolah alam sebagai sumber kegembiraan, bukan lagi menjadikan mereka tegang saat berada didalam ruang kelas. Sekolah alam adalah salah satu bentuk pendidikan yang menggunakan alam sebagai media utama dalam bembelajaran. Sekolah alam menjadikan sebuah impian yang jadi kenyatan bagi mereka yang menginginkan perubahan dalam dunia pendidikan atau sekolah. Belajar akan lebih bersemangat, selain ilmu dari buku yang mereka pelajari mereka bisa langsung mempraktikkan dengan alam.

a. Tujuan sekolah alam

\footnotetext{
${ }^{15}$ Https://Www.Google.Com/Search?Safe=Stict\&Client=Ms-AndroidXiomi\&Ei=Zcdgxptufpoyvqtyzydqaq\&Q=Pengertian+Sekolah+Alam\&Oq Diakses Pada Tanggal 16 Februari 2019

${ }^{16}$ Satmoko Budi Santoso, Sekolah Alternatif, Mengapa Tidak?, (Yokyakarta: Diva Press, 2010) hlm. 13

${ }^{17}$ Arifin, Syamsul. Tesis : Pembelajaran Pendidikan Agama Islam Integratif Di SMA Islam Al-Izhar Pondok Labu. (Jakarta: Sekolah Pascasarjana UIN Syarifhidayatullah. 2009), hlm. 62
} 
Sekolah alam Sekolah alam merupakan pendidikan yang menewarkan konsep pendidikan nilai dan peduli terhadap linkungan alam. Pendidikan dalam konsep sekolah alam merupakan usaha yang dilakukan secara sadar dan jelas. Pada dasarnya sekolah alam didirikan bertujuan untuk mendidik manusia yang beriman dan bertaqwa pada Allah SWT serta berakhlakul karimah. Keberadaan sekolah alam pada dasarnya dalam tujuan kurikulumnya mencakup penciptaan yang baik, penguasaan ilmu pengetahuan dan pemahaman kepemimpinan yang memadai. ${ }^{18}$

Anak didik diharapkan dapat menguasai pengetahuan dengan luas, meskipun belajar di sekolah yang berbasis kurikulum alam. Satu hal yang tidak bisa dilewatkan dari keberadaan sekolah alam adalah komitmennya pada penciptaan pemahaman kepemimpinan. Lebih spesifiknya lagi, siswa tidak dididik menjadi pengikut produk tertentu, tetapi mereka diarahkan menjadi inovator yang mempunyai jiwa kepemimpinan. Orientasinya, menjadikan anak lebih rama dan peduli terhadap lingkungan.

b. Komponen sekolah alam

Sekolah alam memiliki komponen yang khas / berbeda dengan sekolah pada umumnya. Menurut Mogensen dan mayer (2005:69) ada empat komponen yang terdapat di sekolah alam, yaitu komponen pendidikan pedagogi, hubungan internal, hubungan eksternal, dan lingkungan fisik yang berbeda dengan sekolah biasanya. Pada komponen pedagogi, sekolah alam memiliki cara yang berbeda untuk mengorganisasikan atau melaksanakan kegiatan pembelajaran. Dalam belajar, siswa di sekolah alam belajar melalui pengalaman ilmiah, langsung menerapkan pembelajaran secara langsung, dan berbagai aktivitass yang lainnya yang berbeda dengan sekolah pada umumnya. Pada komponen hubungan internal, di sekolah alam ada keseimbangan partisipasi antara siswa, guru, dan anggota lainnya dalam komunitas sekolah termasuk orang tua. Pada komponen hubungan eksternal, sekolah alam selalu berhubungan langsung dengan alam dan masyarakat sekitar. Masyarakat dapat mendukung kegiatan sekolah alam secara finansial, siswapun dapat menggunakann lingkungan luar sekolah sebagai area belajar dan berinteraksi langsung dengan masyarakat. Komponen lingkungan fisik, sekolah alam dirancang khusus agar

\footnotetext{
${ }^{18}$ Satmoko Budi Santoso, Sekolah Alternatif, Mengapa Tidak? (Yogyakarta; Diva Press, 2010), hlm. 18
} 
siswa dan guru dapat mempraktikkan secara langsung kegiatan0kegiatan untuk mengatasi masalah lingkungan.

c. Kurikulum sekolah alam

Seperti lembaga pada umumnya, sekolah alam juga memiliki kurikulum sebagai rencana dan pedoman dalam menyelenggarakan pembelajaran / pendidikan. Satmoko Budi Santoso menjabarkan kurikulum sekolah alam yang terdiri dari 3 hal, yaitu: ${ }^{19}$ 1) penciptaan akhlak yang baik, 2) penguasaan ilmu pengetahuan, 3) Penciptaan pemahaman kepemimpinan yang memadai.

d. Jenis-jenis sekolah alam

Seperti komponen yang khas / berbeda, jenis-jenis kegiatan yang dilakukan di sekolah alam pun berbeda dengan dengan sekolah pada umumnya. Ada beberapa jenis kegiatan di sekolah alam di indonesia, diantaranya yaitu kegiatan outbond, berkebun dan beternak, outing, market day, audiensi, out tracking fun adventure, dan open house (Perdana dan Wahyudi, 2005:35).

\section{Metode penelitian}

Penelitian ini menggunakan pendekatan kualitatif dengan jenis penelitian deskriptif kualitatif. ${ }^{20}$ Penelitian kualitatif dilakukan pada kondisi alami dan bersifat penemuan. Dalam penelitian kualitatif ini peneliti adalah instrumen kunci. Oleh karena itu peneliti harus harus memiliki bekal teori dan wawasan yang luas. Hakikatnya penelitian kualitatif adalah mengamati orang dalam lingkungan hidup yang saling berinteraksi dengan mereka, berusaha memahami bahasa dan tafsiran mereka tentang dunia sekitarnya, mendekati atau saling berinteraksi dengan orang-orang yang berhubungan dengan focus penelitian dengan tujuan mencoba memahami, menggali pandangan dan pengalaman mereka untuk mendapatkan informasi atau data-data yang diperlukan. ${ }^{21}$ Penggunaan metode penelitian kualitatif ini membantu peneliti dalam mengumpulkan informasi yang terkait dengan fokus masalah. Adapun alasan menggunakan metode ini adalah ingin menggali, mangamati, dan mencari data-data yang akurat terkait dengan penelitian tersebut, dan berdasarkan datanya penelitian

\footnotetext{
${ }^{19}$ Satmoko Budi Santoso, Sekolah Alternatif, Mengapa Tidak? (Yogyakarta: Diva Press, 2010), hlm. 18

${ }^{20}$ Lexy J. Moeleong, Metodelogi Penelitian Kualitatif, Edisi Ketiga Puluh (Bandung: PT Remaja Rosdakarya, 2012), hlm. 4

${ }^{21}$ Iskandar, Metodelogi Penelitian Kualitatif, cetakan 1 (Jakarta: Gaung Persada, 2009), hlm. 51
} 
ini menggunakan metode penelitian kualitatif. Peneliti menggunakan metode kualitatif karena ada beberapa pertimbangan antara lain, menjelaskan penyesuaikan metode kualitatif lebih mudah, apabila berhadapan dengan kenyataan, metode ini menyajikan secara langsung hubungan antara peneliti dan responden. Pemilihan jenis penelitian deskriptif kualitatif, didasarkan pada fokus penelitian yaitu bagaimana penerapan pembelajaran terhadap perkembangan mental ABK dan dampak dari sekolah alam terhadap perkembangan mental ABK di sekolah alam MI Bilingial Al-Ikhlas desa sengguruh kepanjen. Data dan sumber penelian, Data dalam penelitian ini berupa data kualitatif hasil observasi, wawancara, dan dokumentasi. Pemilihan lokasi penelitian ini dilakukan hanya dengan satu sekolah inklusif saja yaitu sekolah alam MI bilingual al-ikhlas desa sengguruh kepanjen. Sumber data penelitian terdiri datri data primer dan data sekunder. Sumber data primer diperoleh melalui : kepala sekolah, waka-kurikulum, guru pembimbing, dan orangtua anak ahli surga. Sedangkan data sekunder diperoleh dari berbagai dokumen-dokumen yang relevan lainnya, arsip, dokumentasi, atau buku-buku yang berkaitan dengan kajian penelitian.

\section{Teknik pengumpulan data}

Teknik pengumpulan data yang digunakan meliputi : observasi, wawancara, dan dokumentasi. Teknik observasi dilakukan secara langsung disekolah, dimana peneliti terloibat langsung dalam mengamati kegiatan pembelajaran. Untuk teknik wawancara dapat mendukung informasi yang didapatkan yang berkaitan dengan fokus masalah. Data yang diperoleh adalah berupa data yang tertulis sesuai dengan pedoman wawancara. Penggunakan teknik pengumpulan data dokumentasi meliputi : data kepala sekolah, data pendidik, data peserta didik, program pembelajaran anak ABK, dan foto-fotoTeknik analisi data, Adapun teknik anak lisis data yang digunakan dalam penelitian ini adalah analisis data menggunakan model interaktif yang digambarkan oleh Miles dan Hubarman ${ }^{22}$. Reduksi data diperoleh dilapangan sebelum dilakukan laporan lengkap dan terperinci, yaitu yang memenuhi fokus masalah. Penyajian Data, menyajikan data dalam bentuk laporan berupa uraian singkat, bagan, tabel, grafik, dan sejenisnya. Verifikasi, peneliti melakukan penelitian sebelumnya untuk memastikan kebenaran data karena awal data yang ditemukan masih bersifat sementara dan

\footnotetext{
${ }^{22}$ Huberman A. Mikel \& Miles M.B, Qualitative Data Analisi, (Beverly Hills : SAGE Publication, Inc, 1992), hlm. 16
} 
akan berubah bila tidak di temukan bukti-bukti yang kuat / akurat. Hasil dan pembahasan penelitian, Hasil penelitian diperoleh melalui teknik pengumpulan data yang meliputi, observasi, wawancara, dan dokumentasi. Peneliti akan memaparkan hasil penelitian implementasi pembelajaran terhadap perkembangan mental anka berkebutuhan khusus (ABK) di sekolah alam MI Bilingual Al-Ikhlas desa sengguruh kepanjen.

\section{Penerapan permbelajaran terhadap perkembangan mental anak berkebutuhan khusus (ABK)}

Dari hasil wawancara, mengenai penerapan pembelajaran yaitu guru pendamping selalu menyiapkan Rencana Pelaksanaan Pembelajaran Harian (RPPH) sebelum melaksanakan kegiatan pembelajaran. RPPH tersebut mencakup tema, indikator, kompetensi dasar, tingkat pencapaian perkembangan, kegiatan belajar, alat dan bahan-bahan yang dibutuhkan. Dalam penyusunan penerapan pembelajaran ini guru menggunakan kurikulum individual yang dikombinasikan dengan Kurikulum 2013, yang natinya akan ditinjau kembali oleh kepala madrasah dan disesuaikan dengan kondisi, kebutuhan, dan kemampuan anak. Dalam penerapan pembelajaran guru pendamping juga memprioritaskan kebutuhan anak seperti permainan, media pembelajaran serta kegiatan yang akan dilakuakan anak ahli surga.

Wawancara dengan Wakil Kurikulum :

"Kurikulum yang diterapkan untuk anak ahlli surga adalah kurikulum indivisual yang dikombinasikan dengan kurikulum 2013. Kurikulum individual ini diterapkan untuk memfokuskan guru pendamping terhadap anak ahli surga. Dengan adanya kurikulum individual guru pendamping dapat lebih fokus mematau setiap perkembangan anak"23 Wawancara dengan penannggung jawab / guru pendamping 1 anak ahli surga : "Kurikulum yang digunakan anak ahli surga adalah Kurikulum individual yang dikombinasikan dengan Kurikulum 2013, kenapa menggunakan Kurikulum individual? Karena memang anak ahli surga ini butuh perhatian lebih dibandikan dengan anak normal lainnya, dari cara mereka belajar, tingkah lakunya, bahkan dari cara bersosialisasi mereka. Dan pendekatan pembelajaran yang diterapkan untuk anak-anak adalah pendekatan individual, pendekatan ini mempermudah anak dalam menumbuhkan kemampuan, bakat,

\footnotetext{
${ }^{23}$ Hasil wawancara dengan Abi Lutfi selaku Kepala sekolah dan Kurikulum Madrasah, pada tanggal 26 April 2019
} 
dan minat anak. Pendekatan yang secara langsung dilakukan oleh guru pendamping terhadap anak ahli surga dalam setiap pembelajarannya." ${ }^{24}$ Peneliti juga mewawancarai guru pendamping 3 lainnya : "Menggunakan Kurikulum Individual yang dikombinasikan dengan Kurikulum 2013 dan pendekatan individual dalam proses pembelajarannya, memang dilihat cukup mudah tetapi meskipun kelihatannya lebih mudah kami selaku guru pendamping cukup keteteran dalam setiap program yang akan di ajarkan. Dengan menggunakan pendekatan individual ini membuat kami lebih fokus dalam setiap menangani masing-masing anak ahli surga." ${ }^{25}$ Dari jawaban responden di atas dapat dilihat dari segi perkembangan mental anak memang harus diberikan bimbingan yang intensif dan perhatian yang lebih dalam setiap pertumbuhan dan perkembangannya. Dengan menggunakan kurikulum individual ini guru pendamping akan lebih mudah menyesuaikan dengan kemampuan yang dimiliki anak ahli surga, dan dengan menggukan pendekatan individual dalam setiap pembelajarannya guru pendamping juga bisa selalu melihat setiap perkembangan, pertumbuhan kemampuan, bakat, dan minat anak ahli surga. Wawancara dengan salah satu guru pendamping 2 anak ahli surga :

"Dengan menggunakan pendekatan individual terhadap anak ahli surga sedikit mempermudah saya selaku guru pendamping dalam setiap menerapkan pembelajaran. Mengapa? Karena tidak semua materi belajar dapat dengan mudah diserap oleh anak ahli surga. Dengan pendekatan individual menjadikan saya lebih memahami setiap proses pembelajaran yang diserap oleh mereka." ${ }^{26}$ Hasil wawancara dengan penanggungjawab dan juga guru pendamping 1 anak ahli surga :

"Selain pendekatan individual yang kita lakukan, kita sebagai guru pendamping setiap harinya sebelum pembelajaran yang kita mulai kita berikan terapi ringan yaitu terapi tes jari. Setelah mereka benar-benar siap untuk belajar kita baru bisa memulai pembelajaran, pembelajaran untuk mereka tidak bisa terlalu banyak karena sistem kerja otak mereka berbeda. Ketika mereka sudah cukup untuk menerima materi, sebisa mungkin memang harus selesai meskipun materi yang seharusnya dipelajarinya belum selesai.”27

\footnotetext{
${ }^{24}$ Hasil wawancara dengan Bunda Vika selaku guru pendamping 1 anak ahli surga, pada tanggal 26 April 2019

${ }^{25}$ Hasil wawancara dengan Bunda Kiki selaku guru pendamping 3 anak ahli surga, pada tanggal 26 April 2019

${ }^{26}$ Hasil wawancara dengan Bunda Umi selaku guru pendamping 2 anak ahli surga, pada tanggal 30 Maret 2019

${ }^{27}$ Hasil wawancara dengan Bunda Vika selaku guru pendamping 1 anak ahli surga, pada tanggal 26 April 2019
} 
Peneliti juga mewawancarai Wakil Kurikulum : "Dukungan dari pihak sekolah untuk perkembangan mental anak ahli surga semaksimal mungkin kami lakukan mulai dari terapinya pembelajarannya, dan apa yang mereka butuhkan untuk perkembangan dan pertumbuhan mereka. Meskipun memang dari pihak sekolah masih kurang maksimal dalam memberikan sarana prasarana tetapi kami terus berusaha untuk kedepannya. Semaksimal mungkin kami selalu mensupport dan mendukung anak ahli surga untuk perkembangan mentalnya." ${ }^{28}$ Dari hasil wawancara yang peneliti lakukan dapat disimpulkan bahwa dalam setiap penerapan pembelajaran yang berlangsung setiap harinya sebelum memulai pembelajaran guru pendamping melakukan terapi tes jari untuk pemanasan terlebih dahulu. Untuk penerapan pembelajarannya guru pendamping menggunakan pendekatan individual guna untuk mempermudah memahami dan menfokuskan perkembangan mental anka ahli surga. Dan untuk setiap pembelajarannya anak ahli surga tidak bisa menerima banyak materi, hanya beberapa bagian materi yang bisa diserap oleh mereka.

Selain guru pendamping yang benar-benar membimbing anak ahli surga, orangtua murid juga harus benar-benar mensupport, selalu memberikan motivasi, dan dukungan untuk mereka. Tidak hanya pembelajarn dilingukangan sekolah saja yang diterima oleh anak ahli surga, tetapi mereka juga juga diberikan terapi untuk menunjang perkembangan mereka menjadi lebih baik lagi, Peneliti mewawancarai Abi Lutfi, selaku Kepala Madrasah dan Wakil Kurikulum :"Bukan hanya pembelajaran di sekolah alam yang mereka dapatkan tetapi terapi juga dilakukan oleh pihak sekolah yang langsung bekerja sama dari pihak tutor yang membantu anak untuk terapi dan juga dokter spesialis anak ahli surga. Upaya ini kami lakukan untuk perkembangan anak ahli surga. Selain dari pihak sekolah, murit dan orang tua juga harus sama-sama saling mendukung. Ketika salah satu dari mareka tidak saling mendukung kita akan kesusahan dalam menjalankan progam, jadi orangtua dan dari pihak sekolah sangat berperan penting untuk perkembangan anak ahli surga" ${ }^{29}$ Hal ini juga dijelaskan oleh Bunda Vika selaku penanggung jawab dan guru pendamping 1 anak ahli surga : "Anak ahli surga diberikan terapi 1 minggu 1 kali, ada juga 1 minggu dua kali. Semuanya dilihat dari kemampuan

\footnotetext{
${ }^{28}$ Hasil wawancara dengan Abi Lutfi selaku Kepala sekolah dan Kurikulum Madrasah, pada tanggal 26 April 2019

${ }^{29}$ Hasil wawancara dengan Abi Lutfi selaku Kepala sekolah dan Kurikulum Madrasah, pada tanggal 26 April 2019
} 
anak, karna memang di sisini kurang intensif dalam penanganannya tetapi dari pihak sekolah dan guru benar-benar semaksimal mungkin dalam memberikan apa yang dibutuhkan anak ahli surga. Di lihat dari segi guru pendamping dari kami memang belum ada yang benar-benar guru spesialis untuk menangani anak ahli surga tapi kami selaku guru pendamping dan pihak sekolah selalu belajar, belajar, dan belajar untuk memeberikan yang terbaik untuk anak ahli surga. Selain kami bekerja sama dengan pihak fisioterapi kami juga bekerja sama dengan dokter spesialis untuk anak ahli surga. Karena memang ada makanan tertentu yang tidak boleh mereka konsumsi, seperti semua jenis makanan yang terbuat dari tepung drigu dan tepung ketan, permen, bakso, sate, dan mereka tidak boleh makan durian. Ketika mereka makan-makan yang tidak boleh dimakan menjadikan mereka lebih hiperaktif dan sulit dikendalikan. Otak mereka tidak hanya dibagian kepala tapi juga di bagian usus mereka, sistem penceraannya berbeda dengan kita. Dibagian usus mereka lebih sensitif ketika mereka makan makanan yang tidak boleh dimakan." ${ }^{30}$ Peneliti jug mewawancarai guru pendamping 3 : "Upaya guru pendamping untuk meningkatkan perkembangan mental anak adalah satu satunya ketika pembelajaran belum dipulan kami melaukan terapi tes jari, terapi ringan ini selalu kami lakukan untuk melihat seberapa fokus anak ketika diajak belajar, dan juga kami selalu memberikan hal-hal yang menarik untuk merangsang pembelajaran mereka, seperti contoh ketika ada materi tertentu yang bisa langsung kami praktikkan dengan alam kami langsung ajak mereka untuk mempraktikkannya." ${ }^{31}$ Hal ini juga di jelaskan oleh Bunda Umi : "Untuk penerapan pembelajaran anak ahli surga sejauh ini cukup berkembang, mereka dapat dengan mudah merangsang pembelajaran yang kami berikan. Ini semua membuat kami guru pendamping bahagia dan bangga sama mereka. Kami selalu memberikan pertanyaan-pertanyaan dan pembelajaran yang membuat mereka tertarik dan ketika mereka berhasil menjawab pertanyaan yang kami berikan kami memberikan Bintang / Reward, agar anak didik semakin tertarik dan semakin senang dalam setiap pembelajaran yang mereka terima. Alhamdulillah, sejauh ini perkembangan mental anak semakin berkembang dari waktu ke waktu. Kami berharap penerapan pembelajaran yang

\footnotetext{
${ }^{30}$ Hasil wawancara dengan Bunda Vika selaku guru pendamping 1 anak ahli surga, pada tanggal 26 April 2019

${ }^{31}$ Hasil wawancara dengan Bunda Kiki selaku guru pendamping 3 anak ahli surga, pada tanggal 26 April 2019
} 
kami berikan benar-benar membantu perkembangan mental mereka." ${ }^{32}$ Peneliti mewawancarai salah satu orangtua murid anak ahli surga : "Memang benar kami selaku orangtua benar-benar menjaga pola makan anak, dan sealu memberikan support dalam setiap perkembangannya. Kami juga selalu memberikan yang terbaik untuk kesembuhan mereka, memperikan mereka terapi dan belajar seperti yang lainnya. Dengan hal ini, menjadikan kami benar-benar dekat, menjaganya, dan melihat setiap perkembangan kecil yang mereka perlihatkan." 33

Dari hasil wawancara yang peneliti lakukan, bahwa perkembangan mental anak mereka memang harus selalu dipantau mulai dari pola makanannya, terapinya, bentuk support dari orangtua, guru dan orang-orang terdekat mereka. Anak ahli surga diberikan terapi 1 minggu 1 kali, ada juga 1 minggu dua kali. Terapi ini dilakukan semaksimal mungkin dilakukan untuk perkembangan mental anak. Selain dari pihak sekolah / guru pendamping dan anak ahli surga, orang juga juga ikut serta untuk saling mendung anak dalam setiap proses pembelajarannya. Ketika salah satu dari mereka tidak saling mendukung, tidak saling berjalan bersama itu semua tidak akan berjalan dengan lancar program yang sudah tersusun. Upaya yang diberikan guru dalam meningkatkan perkembangan mental anak adalah memberikan kesempatan untuk menjawab pertanyaan yang diberikan guru / mengerjakan soal yang diberikan guru dan memberikan Bintang / Reward kepada siswa. Peneliti mewawancarai guru pendamping 2 anak ahli surga : "Penerapan pembelajaran terhadap perkembangan mental anak ahli surga, Alhamdulillah sejauh ini cukup berkembangan. Kami tidak menargetkan untuk pembelajaran dan perkembangan mental anak, cukup ada hasil dari apa yang kami lakukan. Untuk penerapannya sejauh ini anak ahli surga Alhamdulilah sudah bisa menerima, merangsang setiap pembelajaran yang kami berikan. Dengan respon yang seperti ini membuat kami semakin ingin terus melatih dan belajar bersama dengan mereka. Dan untuk perkembangan mentalnya, dengan bantuan terapi dalam setiap minggunya, sedikit demi sedikit perkembangan anak ahli surga selalu terlihat mulai dari cara bicaranya, tingkah lakuknya. Bahkan cara bersosialisasi mereka. Sejauh ini kami terus berusaha semaksimal mungkin untuk perkembangan mental anak ahli surga. Perkembangan mereka terlihat setelah 2 minggu

\footnotetext{
${ }^{32}$ Hasil wawancara dengan Bunda Umi selaku guru pendamping 2 anak ahli surga, pada tanggal 30 Maret 2019

${ }^{33}$ Hasil wawancara dengan salah satu bunda anak ahli surga, pada tanggal 30 Maaret 2019
} 
mereka melakukan terapi dan pembelajaran di sekolah alam ini."34 Peneliti juga mewawancarai salah satu orangtua murid anak ahli surga : "Alhamdulillah, perkembangan anak saya lebih baik dari sebelum mereka belajar dan terapi di sekolah alam ini. Awalnya saya pesimis akan hal itu, tapi Alhamdulillah sejauh ini perkembangan mereka semakin meninggkat. Dari penerapan pembelajaran yang mereka terima dan juga terapi yang mereka lakukan, itu semua sudah ada perubahan meskipun memang tidak maksimal tapi setidaknya sudah ada kemajuan. Muaai dari belajarnya yang dulunya mungkin sulit untuk bisa belajar, atau bicara sedikit demi sedikit sudah mulai ada kemajuan. Tingkah lakunya sudah mulai terkendali dan juga cara bersosialisasi mereka dengan oranglain." 35

Dari hasil wawancara yang peneliti lakukan di Sekolah Alam MI Bilingual Al-Ikhlas tentang penerapan pembelajaran terhadap perkembangan mental anak, adalah menggunakan pendekatan individual dalam setiap pembelajaran. Agar tujuan pendidikan tercapai sesuai dengan yang telah dirancang oleh guru, maka guru perlu mengetahui dan mempelajari beberapa penerapan mengajar, lalu diperaktikkan pada saat mengajar. Penerapan pembelajaran merupakan sebuah perencanaan dan pelaksanaan prosedur dan langkah-langkah pembelajaran secara teratur untuk melakukan proses pembelajaran sampai pada tahap penilaian dan evaluasi.

Dalam menerapkan atau menentukan tema pembelajaran guru pendamping menyesuaikan dengan kondisi, kebutuhan, dan kemampuan anak. Kebutuhan nyata anak autisme dalam pembelajaran seperti media pembelajarannya, permainannya, terapi, dan lain sebagainnya. Kemudian guru pendamping juga merenakan tujuan pembelajaran yang akan mereka capai dengan cara anak mengerjakan kegiatan yang diberikan guru pendamping sehingga dalam pemberian materi dan kegiatan guru pendamping merencanakan semuanya dengan menyesuaikan kondisi dan kemampuan anak. Sejauh ini penerapan pembelajaran yang diberikan guru pendamping kepada anak ahli surga dapat diterima dan dirangsang oleh mereka. Dan juga perkembangan mental anak hali surga dapat berkembang dengan baik dan memberikan perubahan yang mendasar bagi mereka. Perubahan ini dilihat dari tingkat laku dan cara bersosialisasi mereka dengan teman-temannya meskipun kadang terkendali. Upaya

\footnotetext{
${ }^{34}$ Hasil wawancara dengan Bunda Umi selaku guru pendamping 1 anak ahli surga, pada tanggal 30 Maret 2019

${ }^{35}$ Hasil wawancara dengan salah satu bunda anak ahli surga, pada tanggal 30 Maaret 2019
} 
yang diberikan guru dalam meningkatkan perkembangan mental anak adalah memberikan kesempatan untuk menjawab pertanyaan yang diberikan guru / mengerjakan soal yang diberikan guru dan memberikan Bintang / Reward kepada siswa.

\section{Dampak dari Pembelajaran Sekolah Alam Terhadap Perkembangan Mental Anak Berkebutuhan Khusus (ABK)}

Saat peneliti melakukan observasi tentang dampak dari pembelajaran sekolah alam terhadap perkembangan mental Anak Berkebutuhan Khusus (ABK), sebagai berikut : Peneliti mewawancarai Abi Lutfi, selaku Kepala Madrasah Ibtidaiyah : "Dampak positif dari pembelajaran sekolah alam bagi anak ahli surga : 1. Siswa lebih interaktif, siap dengan lingkungan diluar; 2. Menjada sikologi anak di dalam lingkungan; 3. Tumbuh secara alami, minat bakat anak sedikit demi sedikit akan terekspost di lingukngan bebas. Dampak negatifnya : alat pembelajaran untuk anak ahli surga kurang memadai, tempat untuk anak surga kurang memadai."

Peneliti mewawancarai oleh Bunda Vika selaku penanggung jawab dan guru pendamping 1 anak ahli surga : "Dampak positif dari pembelajaran sekolah alam bagi anak ahli surga, yaitu : 1. Menjadikan siswa lebih mandiri, 2. Lebih mudah berinteraksi dengan teman lainnya, 3 . Menjadikan siswa lebih akrab dengan alam. Dampak negatif : Ruangan / lingungan yang kurang mendukung untuk anak ahli surga, kurangnya tenaga guru yang benar-benar spesialis untuk menangani anak ahli surga.” Peneliti juga mewawancarai Bunda Umi selaku guru pendamping 2 anak ahli surga : "Dampak positif nya, menjadikan anak ahli surga merasakan bahwa mereka itu sama dengan anak yang lainnya, tidak ada yang beda dan dibeda-bedakan terutama dalam belajar. Untuk dampak negatifnya, alat / media pembelajarannya masih kurang mendukung” Hal ini juga dijelaskan oleh Bunda Kiki selaku guru pendamping 3 anak ahli surga : "Dampak positifnya ruang pembelajaran mereka langsung berinteraksi dengan alam, tanapa ada dinding pembatas yang tinggi, dan dampak negatifnya kurangnya ruangngan khusus untuk anak ahli surga."

Dari hasil wawancara yang peneliti lakukan di Sekolah Alam MI Bilingual Al-Ikhlas, dampak positif dari pembelajaran sekolah alam terhadapan perkembangan mental anak berkebutuhan khusus adalah : 1. Siswa lebih interaktif, siap dengan lingkungan diluar; 2. 
Menjaga sikologi anak di dalam lingkungan; 3. Tumbuh secara alami, minat bakat anak sedikit demi sedikit akan terekspost di lingukngan bebas; 4. Menjadikan siswa lebih mandiri, 5. Lebih mudah berinteraksi dengan teman lainnya, 6. Menjadikan siswa lebih akrab dengan alam, 7 . menjadikan anak ahli surga merasakan bahwa mereka itu sama dengan anak yang lainnya, tidak ada yang beda dan dibeda-bedakan terutama dalam belajar, 8. ruang pembelajaran mereka langsung berinteraksi dengan alam, tanapa ada dinding pembatas yang tinggi. Dampak negatif dari pembelajaran sekolah alam terhadapan perkembangan mental anak berkebutuhan khusus adalah : 1. Alat pembelajaran untuk anak ahli surga kurang memadai, tempat untuk anak surga kurang memadai, 2. Ruangan / lingungan yang kurang mendukung untuk anak ahli surga, 3. Kurangnya tenaga guru yang benar-benar spesialis untuk menangani anak ahli surga, 4. kurangnya ruangngan khusus untuk anak ahli surga.

\section{Kesimpulan}

Sekolah Alam MI Bilingual Al-Ikhlas desa sengguruh Kepanjen sebagai penyelenggara pendidikan inklusif menerima anak berkebutuhan khusus. Pada tahun ajaran 2018/2019 memiliki peserta didik berkebutuhan khusus sebanyak 8 anak yang terdiri dari kelas I = 3 anak, kelas II = 2 anak, kelas III = 2 anak, kelas IV $=1$ anak. Pembelajarannya di bagi menjadi 2 : (1) Bimbingan Kelas / Klasikal, (2) Bimbingan Individual / Spesial. Untuk bimbingan kelas / klasikal ada 4 anak yang sudah mengikuti pembelajaran di kelas bersama dengan anak normal lainnya dan pembelajarannya sudah mengikuti Kurikulum 2013 dan kadang-kadang masih dipantau dalam setiap pembelajarannya dan juga masih dilakukan terapi. Dan 4 anak lainnya masih berada di kelas bimbingan individual / spesialis yang pembelajarannya masih menggunakan kurikulum individual yang dikombinasikan dengan Kurikulum 2013. Kurikulum individual / spesialis ini di padukan dengan kemampuan masingmasing anak dan diberikan terapi dalam setiap mingunya.

Perkembangan mental anak ahli surga selalu dipantau mulai dari pola makanannya, terapinya, bentuk support dari orangtua, guru dan orang-orang terdekat mereka. Anak ahli surga diberikan terapi 1 minggu 1 kali, ada juga 1 minggu dua kali. Terapi ini dilakukan semaksimal mungkin dilakukan untuk perkembangan mental anak. Selain dari pihak sekolah / guru 
pendamping dan anak ahli surga, orang tua juga ikut saling mendukung anak dalam setiap proses pembelajarannya.

Berdasarkan pembahasan fokus masalah yang ditulis salam baba sebelumnya, maka dapat penulis simpulkan sebagai berikut. Pertama, penerapan pembelajaran terhadap perkembangan mental Anak Berkebutuhan Khusus (ABK) adalah menggunakan kurikum ndividual yang dikombinasikan dengan kurikulum 2013 dan pembelajarannya menggunakan pendekatan individual. Pendekatan individual diterapkan untuk lebih fokus lagi terhadap perkembangan anak ahli surga dan mengetahui setiap pertumbuhan kemampuan, bakat, dan minat anak. Dengan pendeketan ini proses pembelajaran berjalan dengan baik, mulai dari penerapan pembelajarannya dan terapi yang di butuhkan anak ahli surga. Upaya yang diberikan guru dalam meningkatkan perkembangan mental anak adalah memberikan kesempatan untuk menjawab pertanyaan yang diberikan guru / mengerjakan soal yang diberikan guru dan memberikan Bintang / Reward kepada siswa. Selain itu, bahwa perkembangan mental anak mereka memang harus selalu dipantau mulai dari pola makanannya, terapinya, bentuk support dari orangtua, guru dan orang-orang terdekat mereka. Selain pihak sekolaha / guru pendamping dan anak ahli surga orang juga juga ikut serta untuk saling mendung anak dalam setiap proses pembelajarannya. Ketika salah satu dari mereka tidak saling mendukung, tidak saling berjalan bersama itu semua tidak akan berjalan dengan lancar program yang sudah tersusun.

Kedua, dampak dari pembelajaran sekolah alam terhadap perkembangan mental Anak Berkebutuhan Khusus (ABK), sebagai berikut : Dampak positif : 1. Siswa lebih interaktif, siap dengan lingkungan diluar; 2. Menjaga sikologi anak di dalam lingkungan; 3. Tumbuh secara alami, minat bakat anak sedikit demi sedikit akan terekspost di lingukngan bebas; 4 . Menjadikan siswa lebih mandiri, 5. Lebih mudah berinteraksi dengan teman lainnya, 6. Menjadikan siswa lebih akrab dengan alam, 7. menjadikan anak ahli surga merasakan bahwa mereka itu sama dengan anak yang lainnya, tidak ada yang beda dan dibeda-bedakan terutama dalam belajar, 8. ruang pembelajaran mereka langsung berinteraksi dengan alam, tanpa ada dinding pembatas yang tinggi. Dampak negatif dari pembelajaran sekolah alam terhadapan perkembangan mental anak berkebutuhan khusus adalah : 1. Alat pembelajaran untuk anak ahli surga kurang memadai, tempat untuk anak surga kurang memadai, 2. Ruangan / lingungan 
yang kurang mendukung untuk anak ahli surga, 3. Kurangnya tenaga guru yang benar-benar spesialis untuk menangani anak ahli surga.

\section{Daftar Pustaka}

Arifin, Syamsul. Tesis : Pembelajaran Pendidikan Agama Islam Integratif Di SMA Islam AlIzhar Pondok Labu. (Jakarta: Sekolah Pascasarjana UIN Syarifhidayatullah. 2009), hlm. 62

Dinie Ratri Desiningrum, Pikologi Anak Berkebutuhan Khusus, cetakan pertama (Yogyakarta: Ruko Jambusari), hlm. 07

Hamzah B. Uno, Perencanaan Pembelajaran, (Jakarta: Bumi Aksara, 2012), hlm. 02

Https://Brainly.Co.Id/Tugas/6154982 Diakses Pada Tanggal 16 Februari 2019

Https://Www.Google.Com/Search?Safe=Stict\&Client=Ms-Android-

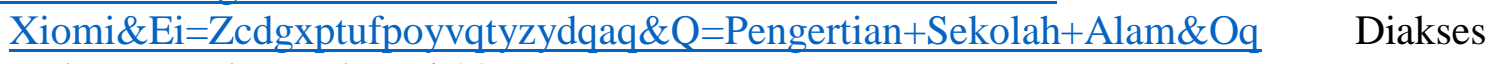
Pada Tanggal 16 Februari 2019

Huberman A. Mikel \& Miles M.B, Qualitative Data Analisi, (Beverly Hills : SAGE Publication, Inc, 1992), hlm. 16

Iskandar, Metodelogi Penelitian Kualitatif, cetakan 1 (Jakarta: Gaung Persada, 2009), hlm. 51

Jati Rinakri Atmaja, Pendidikan Dan Bimbingan Anak Berkebutuhan Khusus, Cetakan Pertama (Bandung: PT Remaja Rosdakarya, 2018), hlm. 06

Lexy J. Moeleong, Metodelogi Penelitian Kualitatif, Edisi Ketiga Puluh (Bandung: PT Remaja Rosdakarya, 2012), hlm. 4

Mohammad Asrori, Psikologi Pembelajaran, Cetakan Pertama (Bandung: CV Wacana Prima, Januari 2007), hlm. 49-51

Muhammad Husni-IAI Al-Qolam, Diferensiasi Peserta Didik Dalam Kebersamaan Di Kelas Inklusi Sekolah Garasi Turen Malang, (Surabaya: UIN Sunan Ampel, 2018), hlm. 479

Nurdin dan Usman, Implementasi Pembelajaran, (Yokyakarta: Rajawali Pers, 2011), hlm. 34

Nur Eva, Psikologi Anak Berkebutuhan Khusus, Cetakan Pertama (Malang: Fakultas Pendidikan Psikologi, 2015), hlm. 02

Satmoko Budi Santoso, Sekolah Alternatif, Mengapa Tidak?, (Yokyakarta: Diva Press, 2010) hlm. 13

Yuda Asmara, Pendekatan Pembelajaran dan Implementasi Dalam Proses Belajar Mengajar, (Jakarta: Rineka Cipta), hlm.06 